\title{
Transcriptional Analysis of Masson Pine (Pinus massoniana) under High $\mathrm{CO}_{2}$ Stress
}

\author{
Fan Wu ${ }^{1}{ }^{1}$, Xiaobo Sun ${ }^{1}$, Bingzhang Zou ${ }^{2}$, Peihuang Zhu ${ }^{1} \mathbb{C}$, Nengqing Lin ${ }^{2}$, Jingquan Lin ${ }^{2}$ \\ and Kongshu Ji ${ }^{1, *(1)}$ \\ 1 Key Laboratory of Forestry Genetics \& Biotechnology of Ministry of Education, Co-Innovation Center for \\ Sustainable Forestry in Southern China, Nanjing Forestry University, Nanjing 210037, China; \\ eiknarf@126.com (F.W.); sun15336229768@163.com (X.S.); zphzhupeihuang@163.com (P.Z.) \\ 2 Baisha state-owned forest farm, Shanghang 364200, China; zbz808@163.com (B.Z.); \\ lnq196308@126.com (N.L.); LJQ1981722@126.com (J.L.) \\ * Correspondence: ksji@njfu.edu.cn; Tel.: +86-025-85427308
}

Received: 23 August 2019; Accepted: 10 October 2019; Published: 13 October 2019

check for Abstract: To explore the molecular mechanism of the response of Masson pine (Pinus massoniana), the
main coniferous tree in southern China, to high $\mathrm{CO}_{2}$ stress, transcriptome sequencing was carried out
to analyze the genome-wide responses of annual seedlings under different durations $(0 \mathrm{~h}, 6 \mathrm{~h}, 12 \mathrm{~h}$ and
$24 \mathrm{~h}$ ) of high $\mathrm{CO}_{2}$ stress. The results showed that a total of $3080 / 1908,3110 / 2115$ and $2684 / 1483$ genes
were up-/down-regulated after $6 \mathrm{~h}, 12 \mathrm{~h}$ and $24 \mathrm{~h}$ of treatment, respectively, compared with control
check group (CK, $0 \mathrm{~h}$ ). Kyoto Encyclopedia of Genes and Genomes (KEGG) analysis showed that most
of these differentially expressed genes (DEGs) were enriched in energy metabolism, carbohydrate
synthesis, cell wall precursor synthesis and hormone regulation pathways. For energy metabolism,
the expression of most genes involved in photosynthesis (including the light reaction and Calvin
cycle) was generally inhibited, while the expression of genes related glycolysis, the tricarboxylic acid
(TCA) cycle and PPP pathway was up-regulated. In addition, the increase in the CO ${ }_{2}$ concentration
induced the up-regulation of gene expression in the sucrose synthesis pathway. Among all starch
synthesis genes, GBSS (granule-bound starch synthase) had the highest expression level. On the other
hand, during the synthesis of hemicellulose and pectin (cell wall precursor substances), the expression
levels of GMD (GDP-mannose 4,6-dehydratase), MGP (Mannose-1-phosphate guanylyl transferase)
and RHM (Rhamnose biosynthetic enzyme) were the highest, suggesting that the synthesis of the raw
materials hemicellulose and pectin in Masson pine under stress were mainly supplied by GDP-Man,
GDP-Fuc and UDP-Rha. Finally, stress inhibited gene expression in the ABA (Abscisic Acid) synthesis
pathway and induced gene expression in the GA (Gibberellin), SA (Salicylic acid), BR(Brassinolide)
and MeJA (Methyl Jasmonate) pathways. Stomatal switches were regulated by hormonal interactions.
This experiment elaborated on the response and molecular mechanism of Masson pine to CO ${ }_{2}$ stress
and aided in screening carbon sequestration genes for the corresponding molecular research of
Masson pine in the future.

Keywords: Masson pine; Pinus massoniana; $\mathrm{CO}_{2}$ stress; transcriptional analysis

\section{Introduction}

As humans enter an industrial society, environmental issues have become increasingly prominent. Global warming has been widely monitored by governments and the public worldwide and has risen to become one of the most important political, diplomatic, and economic issues [1]. According to the Global Carbon Project (GCP), global $\mathrm{CO}_{2}$ emissions from fossil fuels and industry reached $36.8 \mathrm{Gt}$ in 2017, an increase of approximately 65\% from the baseline year (1990) of the Kyoto Protocol [2]. 
And atmospheric $\mathrm{CO}_{2}$ concentrations will rise from $380 \mathrm{ppm}$ today to $550 \mathrm{ppm}$ by 2050 [3]. These numbers are increasing because of the overuse of fossil fuels. Therefore, mitigating global warming caused by the increase in the $\mathrm{CO}_{2}$ concentration in the atmosphere has become a serious global challenge.

Studies have shown that elevated $\mathrm{CO}_{2}$ concentrations cause changes in plant morphological structures [4], reduce stomatal conductance [5] and the leaf nitrogen metabolism rate [6] and impact other reactions. To maintain normal growth and development, plants have developed a series of physiological, biochemical and molecular regulatory mechanisms, including stomatal regulation, ion homeostasis, signal transduction, etc [7]. Tolerance to high $\mathrm{CO}_{2}$ concentrations is a complex trait controlled by genes that play important roles in $\mathrm{CO}_{2}$ stress responses in various plants, including heat shock proteins [8], WRKY [9,10], and other photosynthetic-related genes [11]. These previous studies have indicated that the overexpression of these genes could increase the resistance of plants to $\mathrm{CO}_{2}$ stress and that the tolerance of plants to high concentrations of $\mathrm{CO}_{2}$ could be improved by transgenic and molecular marker-assisted breeding.

Masson pine (Pinus massoniana) is a conifer species distributed in 17 provinces, autonomous regions and municipalities located south of the Qinling Mountains in China. It thrives in a warm and humid climate, growing in arid, barren gravel soil and sandy soil. It is a pioneer species for restoring forests in barren hills [12]. Studies have shown that the carbon sequestration capacity of Masson pine is much higher than the average carbon sequestration of forests in China [13]. The carbon sequestration of each organ of Masson pine is between 533.93 and $568.08 \mathrm{~g} \cdot \mathrm{kg}^{-1}$, which is higher than the carbon content of 32 common tree species $\left(444.0 \sim 494.5 \mathrm{~g} \cdot \mathrm{kg}^{-1}\right)$ [14]. In recent years, there have been many studies on the physiological and biochemical responses to $\mathrm{CO}_{2}$ stress and the screening of candidate $\mathrm{CO}_{2}$-resistance genes [15-17]; however, few studies on the $\mathrm{CO}_{2}$ tolerance mechanism and transcriptome response of Masson pine have been reported. In this study, a next-generation transcriptome sequencing analysis of Masson pine under high $\mathrm{CO}_{2}$ stress was evaluated using the Illumina HiSeq sequencing platform. The transcriptome results were used to identify genes that might be involved in the response to $\mathrm{CO}_{2}$ and to clarify the possible molecular mechanisms involved in the adaptation to $\mathrm{CO}_{2}$ stress. To verify the accuracy of the sequencing results, we selected several genes for quantitative real-time PCR (qRT-PCR) verification. The results improve our understanding of environmental acclimation mechanisms in Masson pine and serve as a molecular-level reference to inform future work on the enhancement of $\mathrm{CO}_{2}$ tolerance in Masson pine.

\section{Materials and Methods}

\subsection{Plant Material and Experimental Conditions}

One-year-old Masson pine seedlings, obtained from the seed orchard of Baisha state-owned forest farm, Shanghang, Fujian Province, China $\left(25^{\circ} 15^{\prime} \mathrm{N}, 116^{\circ} 62^{\prime} \mathrm{E}\right)$, were used in this study. Individuals of the same clones with similar heights, uniform growth and strong growth potential were selected as the test materials and subsequently moved into a growth chamber to recover for $15 \mathrm{~d}$. The growth conditions were $10 \mathrm{~h}$ light $/ 14 \mathrm{~h}$ dark cycles at $25^{\circ} \mathrm{C}$ in the chamber. Air containing about two times of the chamber $\mathrm{CO}_{2}$ concentration before experiment was aerated into the growth chamber constantly for at least $24 \mathrm{~h}$. The $\mathrm{CO}_{2}$ concentration in the chamber was monitored by an infrared $\mathrm{CO}_{2}$ analysis reader (SenseAir, Delsbo, Sweden). The seedlings were sampled after $6 \mathrm{~h}, 12 \mathrm{~h}$ and $24 \mathrm{~h}$ of treatment with the high $\mathrm{CO}_{2}$ concentration, and the needles were selected for downstream experiments.

\subsection{Total RNA Isolation, Complementary DNA Library Preparation and Sequencing}

Total RNA from four treatments $(0 \mathrm{~h}, 6 \mathrm{~h}, 12 \mathrm{~h}$ and $24 \mathrm{~h}$ ) seedlings (Among them, $0 \mathrm{~h}$ treatment was considered as the control check group (CK group)) with three biological replicates for each treatment was extracted using the Plant RNA Isolation Kit (Tiangen, Beijing, China). Sequencing library were constructed using RNA Library Prep Kit for Illumina (NEB, Boston, MA, USA). Then the libraries were sequenced using a Hiseq 4000 (Illumina, San Diego, CA, USA), and generated 150 bp 
paired-end reads. To get clean reads, sequences with length less than $30 \mathrm{bp}$, reads with $N$ ratio over $10 \%$ and without inserted fragments due to reasons such as connector self-connection and adapter sequences were removed using SeqPrep (https://github.com/jstjohn/SeqPrep) and Sickle (https://github.com/najoshi/sickle) [18]

\subsection{Transcriptome Assembly and Functional Annotation}

De novo assembly of all the clean reads was conducted using Trinity version 2.5.0 (https://github. $\mathrm{com} /$ trinityrnaseq/trinityrnaseq/wiki) based on all parameters set as their defaults [19]. Transcripts corresponding to paralogous genes were sorted out to finally obtain the assembly sequences. TransRate software version 1.0.3 (http://hibberdlab.com/transrate/) was used to filter and optimize the initial assembly sequences obtained from Trinity [20], and the assembled sequence was evaluated using BUSCO (Benchmarking Universal Single-Copy Orthologs) version 3.0.2 (http://busco.ezlab.org) [21]. Both of the two softwares ran with their default parameters.

To functionally annotate genes, the sequences were BLASTed in Kyoto Encyclopedia of Genes and Genomes (KEGG) (https://www.genome.jp/kegg/) public databases. KEGG enrichment analysis for the DEGs was carried out by KOBAS version 3.0. In this software, False-positive were assessed by BH (FDR correction with Benjamini/Hochberg) method with a cut-off $E$-value of $10^{-6}$. When the $p$-adjust (the adjusted $p$-value) of a KEGG pathway was less than 0.05 , we considered this KEGG pathway was significantly enriched.

\subsection{Differential Expression Analysis}

The gene expression level for each sample was determined according to the transcripts per million reads (TPM) using RSEM version 1.2.31 (Univ Wisconsin, Madison, WI, USA) with all parameters set as its defaults [22], in which the read counts were normalized using the edgeR package with the Trimmed Mean of M-values method, and then the length of the gene (L) and the normalized counts $(\mathrm{N})$ were used to calculate the TPM $\left(\right.$ TPM $\left.=10^{6} \times\left(\mathrm{N}_{\mathrm{i}} / \mathrm{L}_{\mathrm{i}}\right) / \sum\left(\mathrm{N}_{\mathrm{j}} / \mathrm{L}_{\mathrm{j}}\right)\right)$. The DEGseq $R$ package version 1.10.1 was used to analyze differential expression of different samples [23]. The significant differential expression threshold was set as $q$-value $<0.005$ and $\mid \log _{2}$ (foldchange) $\mid \geq 1$ [24]. The heatmap and differential expression of genes among samples were analyzed using "pheatmap" $R$ package version 1.0.12 (Massachusetts General Hospital, Boston, MA, USA).

\subsection{Quantitative Real-Time PCR Validation}

To validate the RNA-sequencing (RNA-seq) results, the expression levels of nine genes were measured using qRT-PCR. Reaction mixtures consisted of $10 \mu \mathrm{L}$ of $2 \times$ TOP Green qRT-PCR SuperMix (TOYOBO Biotech, Shanghai, China), $0.4 \mu \mathrm{L}$ of forward primer and reverse primer, $2 \mu \mathrm{L}$ of complementary DNA (cDNA), $0.4 \mu \mathrm{L}$ of $50 \times$ Passive Reference Dye and $6.8 \mu \mathrm{L}$ of $\mathrm{ddH}_{2} \mathrm{O}$. The PCR program was set up in six stages: (1) $94{ }^{\circ} \mathrm{C}$ for $30 \mathrm{~s}$ (preincubation), (2) $94{ }^{\circ} \mathrm{C}$ for $5 \mathrm{~s}$, (3) $55^{\circ} \mathrm{C}$ for $15 \mathrm{~s},(4) 72{ }^{\circ} \mathrm{C}$ for $10 \mathrm{~s}$, repeated 40 times (amplification), (5) $95^{\circ} \mathrm{C}$ for $0.5 \mathrm{~s}$, and (6) $60^{\circ} \mathrm{C}$ for $1 \mathrm{~min}$ (melt). The PCR quality was estimated based on melting curves. TUA (Alpha-tubulin) was used as the internal control [25]. The gene-specific primers employed are shown in Table A1 from Appendix A. Three independent biological replicates and three technical replicates for each biological replicate were run. Quantification was achieved using comparative cycle threshold $(\mathrm{Ct})$ values, and gene expression levels were calculated using the $2^{-\Delta \Delta \mathrm{Ct}}$ method [25]. The significance was determined by $t$-test using SPSS statistical software (IBM, New York, NY, USA) $(p<0.05)$.

\section{Results}

\subsection{Transcriptome Sequencing and De Novo Assembly}

The cDNA libraries of the four treatments $(0 \mathrm{~h}(\mathrm{CK}), 6 \mathrm{~h}, 12$, and $24 \mathrm{~h})$ were sequenced and generated a total number of 49,314,299, 47,459,322, 45,980,036, and 60,876,932 raw reads and 48,795,571,46,976,134, 
45,496,760, and 60,205,674 clean reads, respectively (Table 1). The raw data and sequences can be found online at the NCBI (https://www.ncbi.nlm.nih.gov/) Sequence Read Archive (SRA) database (accession number PRJNA561037). Compared with the reference sequences obtained from Trinity assembly, there were generated a total number of 16,879,027,16,459,249,15,859,340 and 21,108,414 mapped reads of $0 \mathrm{~h}, 6 \mathrm{~h}, 12 \mathrm{~h}$, and $24 \mathrm{~h}$ treatments, respectively. An average mapped ratio of $70 \%$ was obtained. The Q30, a key parameter that represents the quality of sequenced bases, was $94.04 \%, 94.22 \%, 93.86 \%$ and $93.4 \%$ for the $0 \mathrm{~h}, 6 \mathrm{~h}, 12 \mathrm{~h}$, and $24 \mathrm{~h}$ treatments, respectively (Table 1 ).

Table 1. Summary of sequencing data quality control.

\begin{tabular}{ccccc}
\hline & $\mathbf{C K}$ & $\mathbf{6} \mathbf{h}$ & $\mathbf{1 2} \mathbf{~ h}$ & $\mathbf{2 4} \mathbf{h}$ \\
\hline Raw reads & $49,314,299$ & $47,459,322$ & $45,980,036$ & $60,876,932$ \\
Raw bases & $7,446,459,199$ & $7,166,357,723$ & $6,942,985,436$ & $9,192,416,732$ \\
Clean reads & $48,795,571$ & $46,976,134$ & $45,496,760$ & $60,205,674$ \\
Clean bases & $7,292,383,178$ & $7,017,302,463$ & $6,802,876,221$ & $9,000,454,730$ \\
Error rate (\%) & 0.02 & 0.02 & 0.03 & 0.03 \\
Mapped reads & $16,879,027$ & $16,459,249$ & $15,859,340$ & $21,108,414$ \\
Mapped ratio (\%) & 0.69 & 0.70 & 0.70 & 0.70 \\
GC content (\%) & 47.47 & 46.74 & 46.24 & 46.32 \\
Q20 (\%) & 98.12 & 98.20 & 98.06 & 97.86 \\
Q30 (\%) & 94.04 & 94.22 & 93.86 & 93.40 \\
\hline
\end{tabular}

The Trinity software generated 140,863 transcripts with an average length of $891 \mathrm{bp}$ and an N50 of $1463 \mathrm{bp}$. In total, 92,424 unigenes were obtained in the range of 201 15,491 bp. Of these, 48,592 (52.57\%) were less than 500 bp, 22,267 (24.09\%) were 501 1000 bp, 12,887 (13.94\%) were 1001 2000 bp and the remaining 8678 (9.39\%) were $>2000 \mathrm{bp}$ (Table 2). TransRate and software BUSCO evaluated the assembly results, and transcript score was 0.20045 and $77.7 \%$, respectively, and unigenes was 0.30498 and $74.2 \%$, respectively (Table 2). According to previous reports [26,27], in Masson pine, unigene obtained by transcriptome sequencing under other stress treatments ranged from 70,896 to 101,806. Our results were similar to them. Combined with the N50 and Q30, we believe that the sequencing results are relatively reliable and could be further analyzed.

Table 2. Length distribution and software evaluation of unigenes and transcripts.

\begin{tabular}{ccc}
\hline Type & Transcript & Unigenes \\
\hline$<500 \mathrm{bp}$ & 61,696 & 48,592 \\
$501 \sim 1000 \mathrm{bp}$ & 37,586 & 22,267 \\
$1001 \sim 2000 \mathrm{bp}$ & 25,994 & 12,887 \\
> 2000 bp & 15,587 & 8,678 \\
Total & 140,863 & 92,424 \\
Min length (bp) & 201 & 201 \\
Max length (bp) & 15,491 & 15,491 \\
Mean length (bp) & 891 & 935 \\
N50 (bp) & 1463 & 1550 \\
TransRate score & 0.20045 & 0.30498 \\
BUSCO score & $77.7 \%$ & $74.2 \%$ \\
\hline
\end{tabular}

\subsection{Gene Expression and KEGG Enrichment Analysis under $\mathrm{CO}_{2}$ Stress}

A total of 7088 genes were differentially expressed between the samples from the three $\mathrm{CO}_{2}$ stress treatments and the control samples. Of these, 4988, 5225 and 4167 genes were differentially expressed between $6 \mathrm{~h}$ and CK, $12 \mathrm{~h}$ and CK, and $24 \mathrm{~h}$ and CK treatments, respectively (Figure 1A). Among the differentially expressed genes (DEGs), 3080/1908, 3110/2115 and 2684/1483 genes were up-/down-regulated at 6 h, 12 h, and 24 h, respectively, compared with CK (Figure 1B). Gene enrichment analysis of the DEGs based on KEGG analysis revealed that these genes were mainly involved in 
several pathways at different time points, including photosynthesis, carbon fixation (the Calvin cycle), glycolysis, the tricarboxylic acid (TCA) cycle, starch and sucrose metabolism, fructose and mannose metabolism, galactose metabolism and plant hormone signal transduction, etc. (Figure 1C,D,E). In the three KEGG enrichment Figures that compare the different treatment time points with CK, all of the above pathways ranked within the top 20 pathways (except the "TCA cycle" in $6 \mathrm{~h} / \mathrm{CK}$, Figure 1C), indicating that energy metabolism, carbohydrate synthesis, cell wall synthesis and hormone regulation may be the main metabolic activities in Masson pine under high $\mathrm{CO}_{2}$ stress.

A

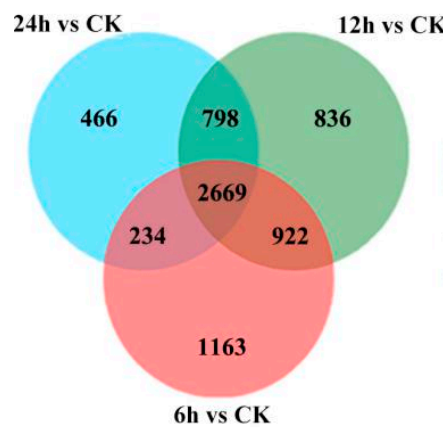

B

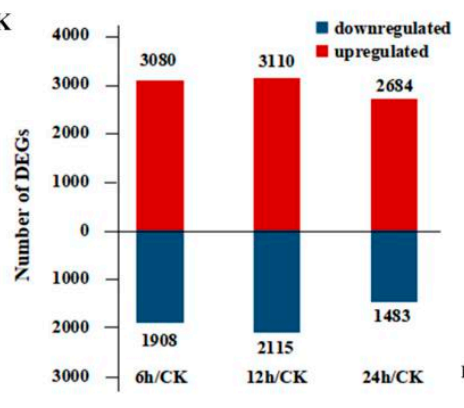

\section{C}

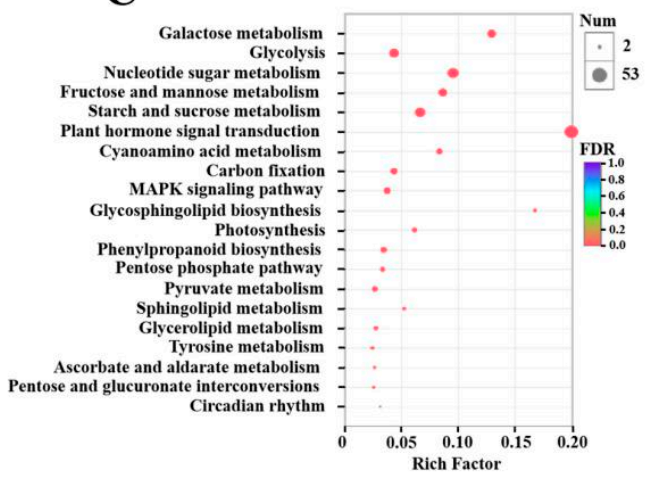

E

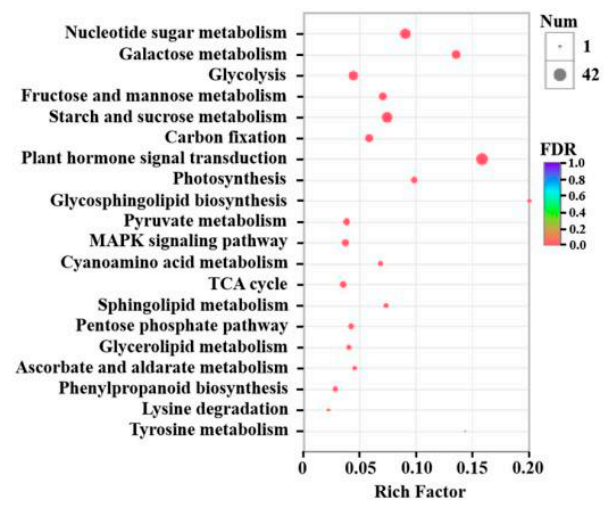

Figure 1. Differential gene expression in seedlings under high $\mathrm{CO}_{2}$ stress. (A) Venn diagram of differentially expressed genes. (B) Statistical map of differentially expressed genes between different comparisons. Red and blue represent up- and down-regulated expression, respectively. (C-E) The top 20 pathways in the KEGG enrichment analysis of CK compared with the $6 \mathrm{~h}, 12 \mathrm{~h}$ and $24 \mathrm{~h}$ treatments, respectively. CK: $0 \mathrm{~h}$ or control check group.

\subsection{Energy Metabolism under Elevated $\mathrm{CO}_{2}$ Stress}

Figure 2 shows the energy metabolic pathways and the general pattern of the relative changes in the related gene expression patterns in Masson pine under high $\mathrm{CO}_{2}$ concentration conditions. Notably, in the transcriptome data, the pathways involved in energy metabolism were polarized. After Masson pine had been exposed to $\mathrm{CO}_{2}$ stress, in the photosynthesis pathways, including the photoreactions and Calvin cycle (Figure 2A, black arrow), the relative expression of each gene in the metabolic pathway except for GAPD (glyceraldehyde-3-phosphate dehydrogenase) showed a downward trend (Figure 2B). GAPD catalyzes 3-phosphoglyceraldehyde (PGAL) to 1,3-diphosphoglycerate (1,3-DPG) in the Calvin cycle and 1,3-DPG to dihydroxy-acetone phosphate (DHAP) in the Embden-Meyerhof-Parnas (EMP) pathway (Figure 2A, orange arrow). Since GAPD plays a role in these two metabolic pathways, the change in its expression patterns may be the result of superposition. Moreover, the gene expression patterns involved in both photosynthesis and other metabolic pathways (such as RPI (Ribulose 
Phosphate Isomerase) or RPE (Ribulose Phosphate Epimerase)) decreased more slowly than those involved only in photosynthesis (such as RCA (Rubisco Activase) or FBP (Fructose-1,6-diphosphate)). On the other hand, the relative expression levels of genes in other pathways involved in energy anabolism, including the EMP pathway, the pentose phosphate (PPP) pathway (Figure 2A, blue arrow) and TCA (Figure 2A, green arrow), generally increased (Figure 2B). Among them, the expression rate of OGDC ( $\alpha$-ketoglutarate dehydrogenase) increased the fastest and was 4.8, 6.09 and 6.18 times that of $\mathrm{CK}$ at $6 \mathrm{~h}, 12 \mathrm{~h}$ and $24 \mathrm{~h}$, respectively. In general, the omics data revealed that energy metabolism was strongly enhanced for contributing to elevated $\mathrm{CO}_{2}$ tolerance in Masson pine, except for the light reaction and Calvin cycle.
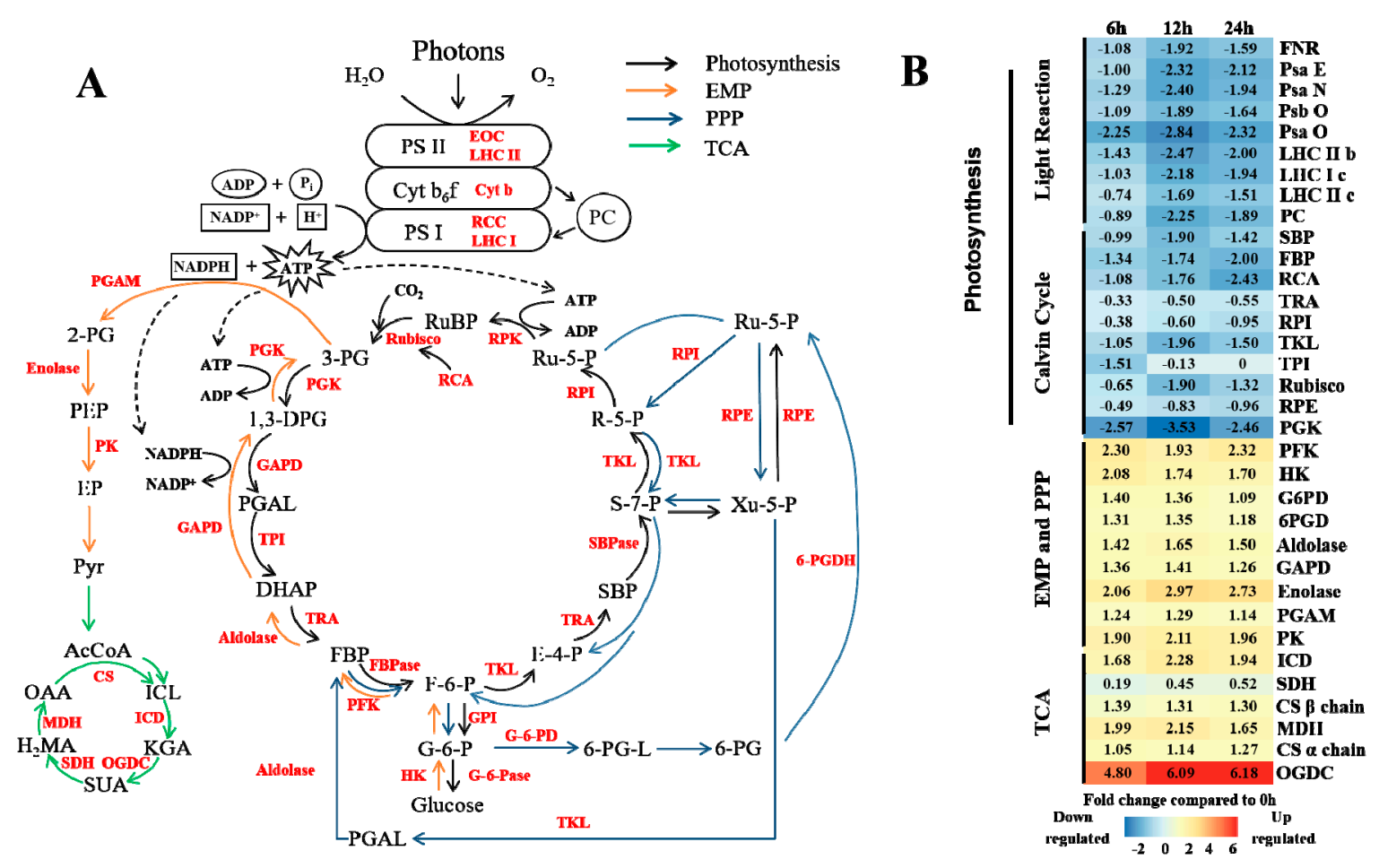

Figure 2. Influence of high $\mathrm{CO}_{2}$ concentration on energy metabolism. (A) The main energy pathways in plants. Black, orange, blue and green arrows represent photosynthesis, the Embden-Meyerhof-Parnas (EMP) pathway, the pentose phosphate (PPP) pathway and the tricarboxylic acid (TCA) cycle, respectively. The different enzymes are shown in red font. (B) Expression changes in the genes involved in metabolic pathways in response to stress. White indicates no change, red up-regulation, and blue down-regulation in each treatment, as shown in the color bar for a $\log _{2}$ fold change scale. The abbreviations in the figure are shown in Table A2 from Appendix A.

\subsection{Biosynthesis of Sucrose, Starch and Cell Wall Components under Elevated $\mathrm{CO}_{2}$ Stress}

The expression levels of the genes in the sucrose and starch synthesis pathways generally showed a trend of up- or slightly down-regulation under $\mathrm{CO}_{2}$ stress conditions compared with $\mathrm{CK}$, except for AGP (Adenosine Diphosphoglucose Pyrophosphorylase) and SBE (Starch Branching Enzyme) (Figure 3B). AGP catalyzes adenosine diphosphate glucose (ADP-Glc) from glucose-1-phosphate (G-1-P), and its expression continued to decline with increasing stress time. On the other hand, among the genes in starch metabolic pathway, the expression of GBSS (Granule-bound Starch Synthase) was higher than SSS (Soluble Starch Synthase) and SBE.

After a series of reactions, triose phosphate was transformed into UDP-Glc in the cytoplasm (Figure 3A), and then it was catalyzed to sucrose by sucrose-phosphate synthase (SPS). After being subjected to stress treatment, the expression levels of SPS at $6 \mathrm{~h}, 12 \mathrm{~h}$ and $24 \mathrm{~h}$ were no significant difference (Figure 3B). Meanwhile, sucrose can be transformed to UDP-Glc and hexose by sucrose 
synthase (SUS) and cell wall invertase (cwINV), and hexose can then be catalyzed by cytosolic invertase (INV) to form fructose-6-phosphate (F-6-P) and glucose-6-phosphate (G-6-P), which are the synthetic precursors of UDP-Glc (Figure 3A). In the above series of reactions, the expression of SUS, cwINV and $I N V$ were up-regulated in different degrees under $\mathrm{CO}_{2}$ stress compared with $\mathrm{CK}$. In addition, UDP-Glc is the precursor for cellulose synthesis, which is catalyzed by cellulose synthase complex (CSC), including cellulose synthase subunit (CesA), cellulose synthase (Csl) and its isoenzymes (Figure 3A). The experimental results showed that the expression levels of CesA, Csl A, Csl C and Csl D were up-regulated with increasing stress time. However, Csl B and Csl E decreased at the same time (Figure 3B). In general, the omics data revealed that gene expression patterns in sugar and cell wall component metabolic pathways were enhanced under elevated $\mathrm{CO}_{2}$ stress in Masson pine.

A

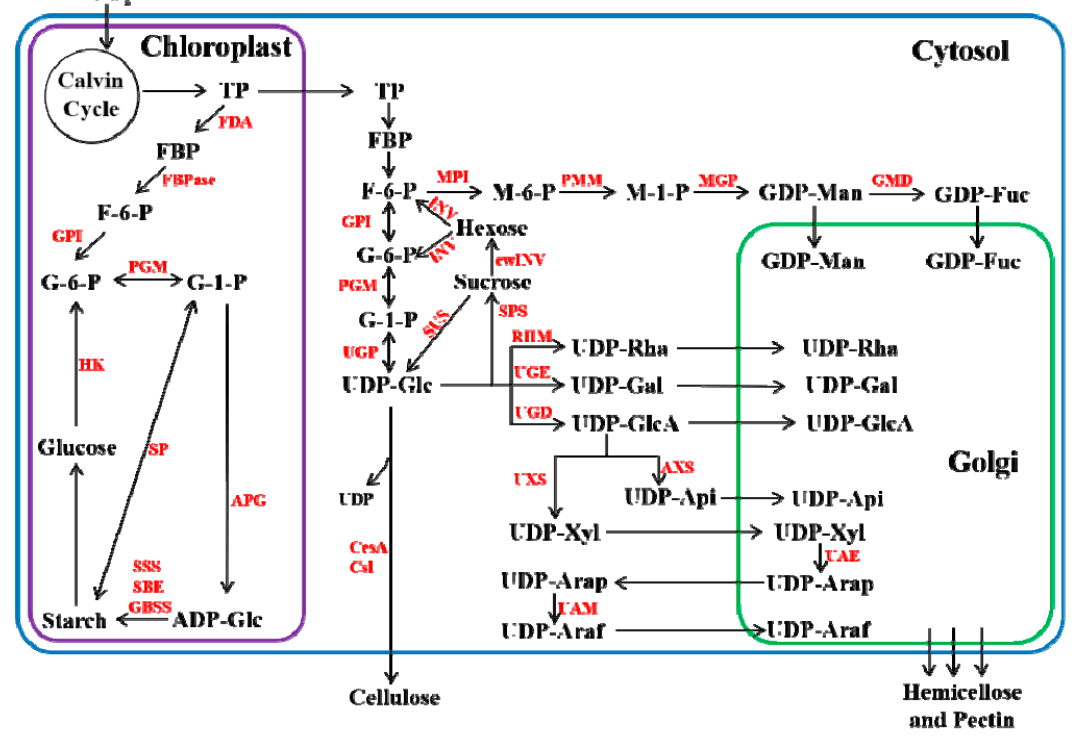

B

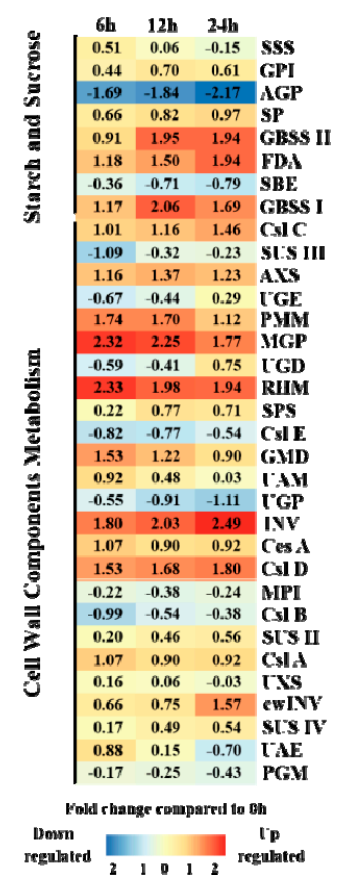

Figure 3. Influence of high $\mathrm{CO}_{2}$ concentration on sucrose, starch and cell wall components. (A) The sucrose, starch and cell wall component biosynthesis pathways according to Evžen [28] and Jana [29]. The blue, purple and green rectangles represent the cytosol, chloroplast and Golgi, respectively. The different enzymes are shown in red font. (B) Expression changes in the genes involved in metabolic pathways in response to stress. White indicates no change, red up-regulation, and blue down-regulation in each treatment, as shown in the color bar for a $\log _{2}$ fold change scale. The abbreviations in the figure are shown in Table A2 from Appendix A.

\subsection{Hormone Regulation under Elevated $\mathrm{CO}_{2}$ Stress}

Based on previous studies [30-33], combined with KEGG analysis results, the expression patterns of 5 plant hormones (ABA, GA, SA, BR and JA) and their corresponding synthesis genes under $\mathrm{CO}_{2}$ stress were analyzed in this study. In the ABA synthesis pathway, except for the expression of ZEP (zeaxanthin epoxidase) that was slightly up-regulated (no significant difference from CK), all other genes were down-regulated. Among them, NCED (9-cis-epoxycarotenoid dioxygenase) decreased most obviously (Figure 4B). and the log2 fold changes in expression compared to CK decreased 4.73, 6.10 and 5.38 times at $6 \mathrm{~h}, 12 \mathrm{~h}$ and $24 \mathrm{~h}$, respectively.

On the other hand, the genes expression pattern of the other four hormones showed an increasing trend under $\mathrm{CO}_{2}$ stress. The key enzyme in the GA metabolic pathway is geranyl geranyl pyrophosphate (GGPS), which catalyzes the synthesis of geranylgeranyl pyrophosphate (GGPP) from isopentenyl 
pyrophosphate (IPP), geranyl pyrophosphate (GPP) and farnesyl pyrophosphate (FPP). Under $\mathrm{CO}_{2}$ stress, GGPS expression increased continuously with time (Figure 4B).

As shown in Figure 4A, SA can be synthesized via two routes, by isochorismic acid (ICA) and by cinnamic acid ( $\mathrm{Ca})$, benzoic acid $(\mathrm{Ba})$, etc. The specific genes involved in the first pathway have not yet been thoroughly studied [34], while the second pathway has been well researched. Under $\mathrm{CO}_{2}$ stress, $P A L$ expression continued to increase, reaching a peak at $12 \mathrm{~h}$ and then stabilizing (there was no significant difference between $24 \mathrm{~h}$ and $12 \mathrm{~h}$ ). Due to the expression pattern of $P A L$, we speculated that the pathway used for SA synthesis in Masson pine under $\mathrm{CO}_{2}$ stress was mainly the second pathway.

The BR synthesis pathways include early (Figure 4A, yellow block) and advanced (blue block) C-6 synthetic pathways [35]. Intermediate metabolites in the advanced pathway could be converted to corresponding metabolites in the early pathway. However, at the upstream pathway, the conversion efficiency was not very high because the expression levels of ROT (C-23 hydroxylase) was down-regulated with increasing treatment time. In contrast, downstream of the pathway, due to the increase in CYP expression (Figure 4B), BR might be synthesized through the early pathway. Overall, both metabolic pathways showed increased efficiency under $\mathrm{CO}_{2}$ stress (Figure 4B).

All genes in the JA (MeJA) synthetic pathway were up-regulated under $\mathrm{CO}_{2}$ stress. Among them, $A O C$ (allene oxide synthase) was the most significantly up-regulated. At $6 \mathrm{~h}$, the relative expression level of $A O C$ was 2.84 times that of $C K$ and then increased, and may continue to increase with increased treatment time. Within $24 \mathrm{~h}$, the expression of $A O C$ was far higher than that of the other genes in the pathway (Figure $4 \mathrm{~B}$ ). It could be speculated that $A O C$ might be a key gene involved in the induction of JA production in Masson pine under high $\mathrm{CO}_{2}$ concentrations.

$\mathbf{A}$

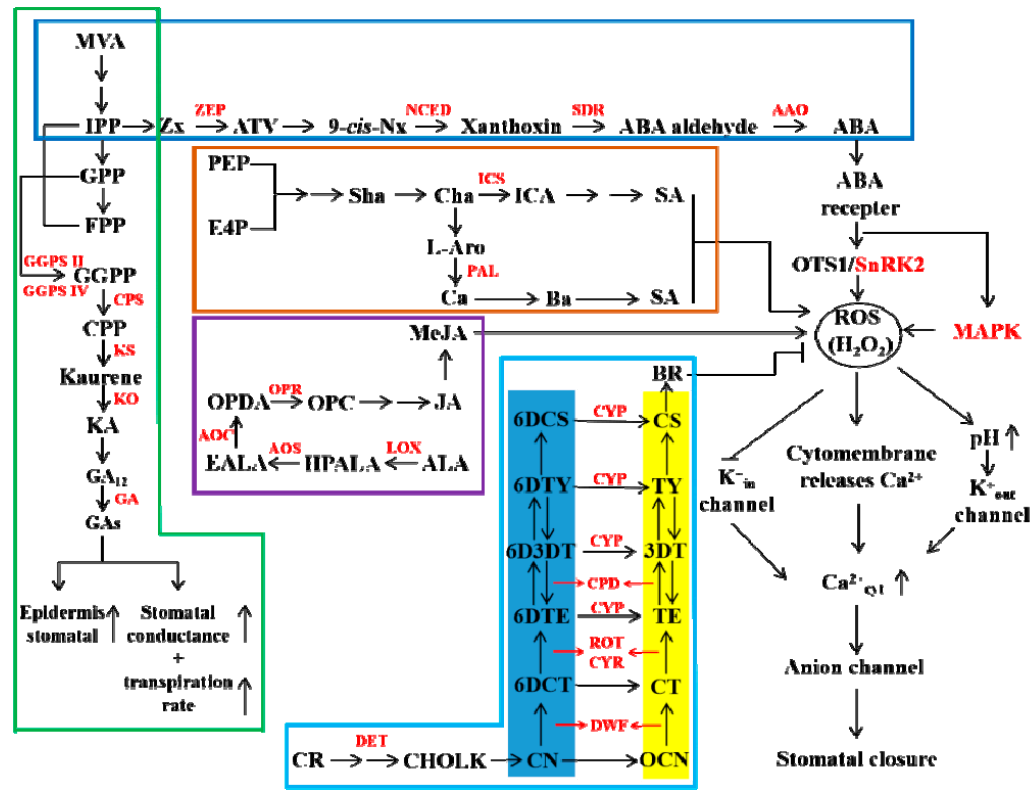

B

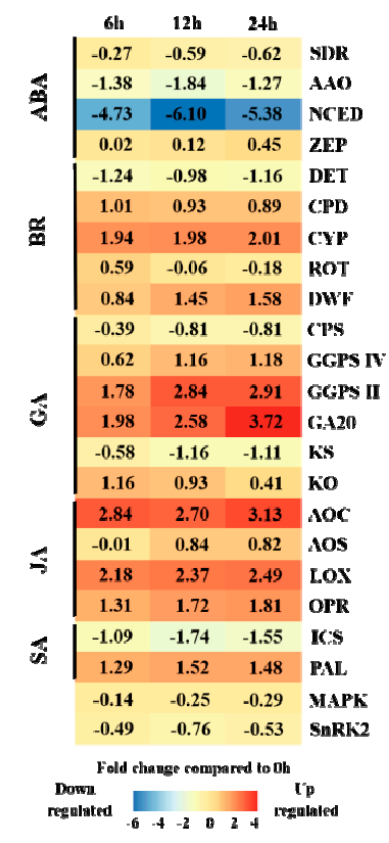

Figure 4. Influence of high $\mathrm{CO}_{2}$ concentration on hormone and stomatal regulation. (A) The hormone biosynthesis pathways and stomatal regulation mechanism according to Zhao [35]. The mazarine, green, brown, purple and wathet frame represents ABA, GA, SA, JA and BR synthetic pathways, respectively. The blue and yellow block represents advanced and early C-6 oxidation pathway in BR biosynthesis, respectively. The different enzymes are shown in red font. Sharp and T-shaped arrows indicate positive and negative regulation, respectively. (B) Expression changes in the genes involved in metabolic pathways in response to stress. White indicates no change, red up-regulation, and blue down-regulation in each treatment, as shown in the color bar for a $\log _{2}$ fold change scale. The abbreviations in the figure are shown in Table A2 from Appendix A. 


\subsection{Validation by Quantitative Real-Time PCR}

To verify the reliability of the transcriptome data, nine genes showing significant up- or down-regulation in the stressed seedlings were randomly chosen for qRT-PCR analysis (Figure 5). Among them, PAL showed constitutively up-regulated expression, and CYP increased at first and reached maximum expression at $6 \mathrm{~h}$, after which there was no significant change. Compared with $\mathrm{CK}, 6 \mathrm{~h}, 12 \mathrm{~h}$ and $24 \mathrm{~h} \mathrm{CO}$ treatments had up-regulated levels of $R H M$ and $O P R$, and the relative expression levels of these genes were higher at $6 \mathrm{~h}$ than at $12 \mathrm{~h}$ and $24 \mathrm{~h}$. On the other hand, enolase had the same trend as RHM and OPR, except that the maximum value appeared at $12 \mathrm{~h}$. CPS and $S B P$ showed constitutively down-regulated expression, and TPI (triose-phosphate isomerase) showed a trend of first decline and then increase. Among all genes, the qRT-PCR results of 6 genes $(C Y P$, $C P S, O P R, P A L, S B P$ and TPI) were very close to the RNA-seq (via the TPM algorithm) results. The expression trend of RHM and enolase was similar to that of RNA-seq, but the fold change in qRT-PCR expression was lower than that in the RNA-seq data. The qRT-PCR results of Ces $A$ were quite different compared with the RNA-seq results. In general, the RNA-seq data were similar to the gene expression trend shown by qRT-PCR analysis, indicating that the results of RNA-seq analysis were effective.

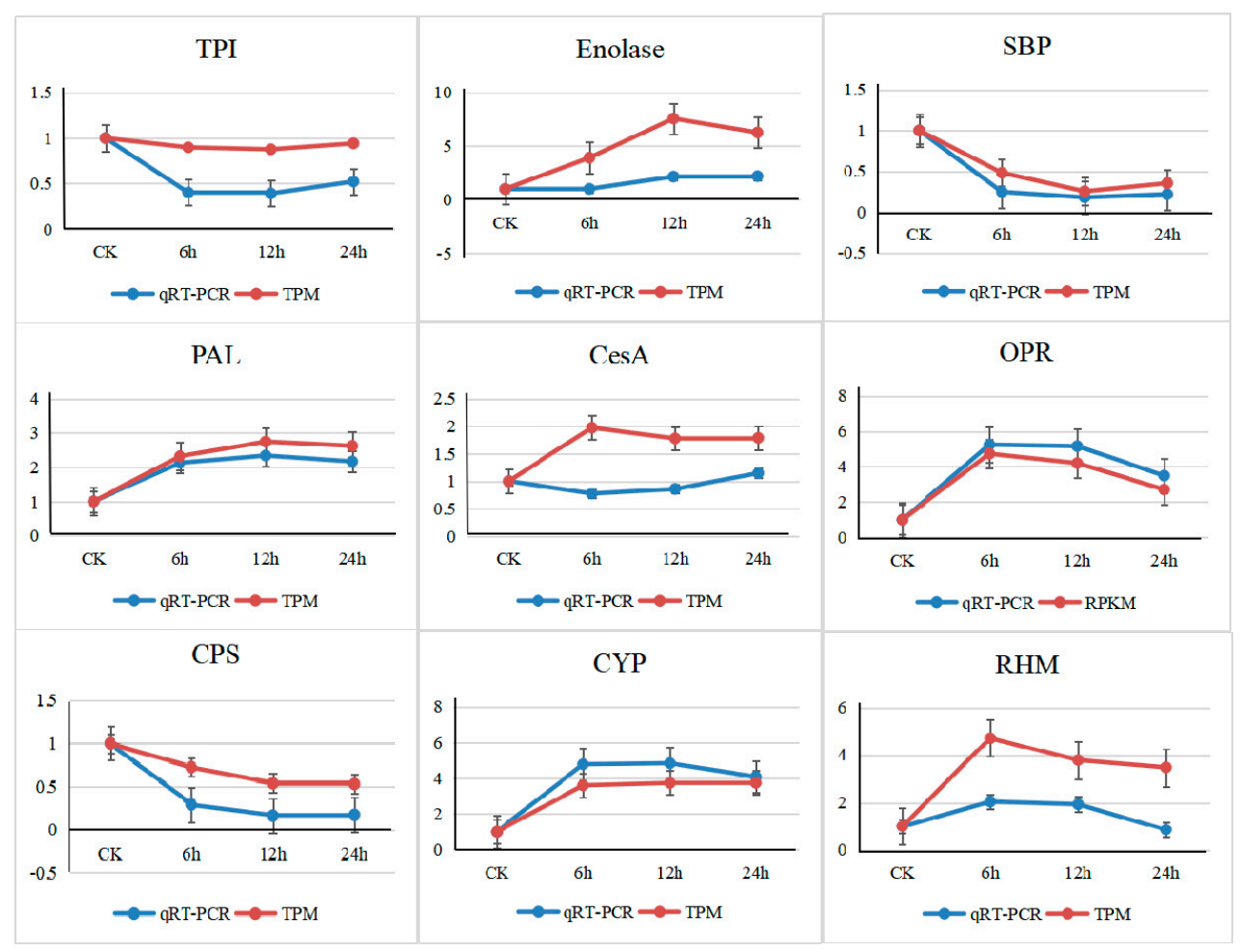

Figure 5. The expression changes in the 9 randomly selected genes were determined using quantitative real-time PCR (qRT-PCR) results and sequencing data. The $x$-axis represents different processing times, and the $y$-axis represents changes in gene expression under $\mathrm{CO}_{2}$ stress. The data show the fold change in the expression of each gene under high $\mathrm{CO}_{2}$ relative to control conditions. Error bars represent standard deviations. Red indicates the RNA-sequencing results under the TPM (transcripts per million reads) algorithm, and blue indicates the qRT-PCR results.

\section{Discussion}

\subsection{Effects of Elevated $\mathrm{CO}_{2}$ on Masson Pine Energy Metabolism}

The results of this study showed that in the major energy metabolism pathways of Masson pine, the expression levels of most genes involved in photosynthesis, including light and dark reactions, showed a significant downward trend under $\mathrm{CO}_{2}$ stress. We speculate the main cause of this phenomenon 
should be the decrease in the expression of Rubisco, which is a key enzyme in photosynthetic carbon assimilation, directly affecting the photosynthetic efficiency of Masson pine [36]. Combined with the up-regulated of key genes in the carbohydrate metabolism during the same period (Figure 3B), it leads to the activation of its signaling pathway, which inhibits the expression of $R b c S$ (Rubisco small subunit) and other photosynthesis-related protein-coding genes through hexokinase transmission, thereby affecting the photosynthetic efficiency [37].

Significantly, previous studies $[38,39]$ have shown the expression of Rubisco will show an up-regulated trend under the high $\mathrm{CO}_{2}$ treatment condition. But the results of this experiment are the opposite. This may be because the expression of carbon sequestration gene is greatly affected by the leaf age [40]. The photosynthetic acclimation of coniferous leaves in one-year needles under high $\mathrm{CO}_{2}$ treatment was more obvious than that in mature coniferous leaves [41]. According to the experimental results, the expression of each gene in photosynthesis showed a downward trend when the sample was analyzed at the shortest detection time $(6 \mathrm{~h})$. Therefore, we speculate the photosynthetic acclimation should be completed within $6 \mathrm{~h}$.

However, in other energy metabolism pathways of Masson pine, the expression levels of various genes under high $\mathrm{CO}_{2}$ stress generally showed an upward trend. Fukayama et al. [42] obtained similar results in an experiment on the effect of $\mathrm{CO}_{2}$ on rice, but the difference in gene expression was inferior to our study, possibly because rice belongs to herbage, and the adaptability of rice to $\mathrm{CO}_{2}$ stress is higher than that of Masson pine. Previous studies found that a high concentration of $\mathrm{CO}_{2}$ promoted the production of a large amount of sucrose in leaves, and the increase in sucrose concentration induces the expansion of glycolytic flux in plants and simultaneously increases the distribution of carbon in the organic acid and TCA cycles, thereby regulating the increase in related gene expression [43].

\subsection{Effects of Elevated $\mathrm{CO}_{2}$ on Masson Pine Carbohydrate and Cell Wall Component Synthesis}

In photosynthetic cells, fixed carbon eventually transforms into sucrose and starch. These compounds are the main form of carbohydrate transport and storage in advanced plants. SPS, SUS and INV are considered to be the key genes in the sucrose synthesis pathway [44]. The results of our experiment suggest that there were no significant differences in SPS and SUS levels between the CK and different treatments, while INV showed an increased difference. This result suggested that, sucrose produced by photosynthesis was more likely to be decomposed into glucose-6-phosphate (G-6-P) and fructose-6-phosphate (F-6-P), and then participated in subsequent reactions is the main metabolic direction of sucrose under high $\mathrm{CO}_{2}$ stress. Van et al. [45] found that INV was significantly up-regulated and SUS was relatively inhibited in mature leaves of in vitro tomato plantlets with high $\mathrm{CO}_{2}$ stress under the condition of providing exogenous sucrose (3\%). In addition, other studies also showed that the expression of INV and the contents of glucose and fructose in leaves increased under cold, $\mathrm{NaCl}$, PEG and other stress conditions, which showed similar phenomena to $\mathrm{CO}_{2}$ stress conditions $[46,47]$.

In the starch synthesis pathway, three different starch-formed synthetases (GBSS, SSS and SBE) are the key regulatory enzymes. In this study, the expression level of GBSS were significantly higher than that of $S B E$ and SSS under high $\mathrm{CO}_{2}$ stress. GBSS generates a branchless linear glucan starch chain (amylose) by specific binding to starch granules, which is necessary for the production of amylose [48]. Due to the high expression of GBSS, we suspected that, amylose was more inclined to synthesize under high $\mathrm{CO}_{2}$ stress in Masson pine. The similar results were confirmed in Cui [49] study. He found that the $\mathrm{CO}_{2}$ stress could significantly improve the activity of GBSS in winter wheat, resulting in a large amount of amylose production, and the expression level increased first and then decreased, which was similar to this experiment.

\subsection{Effects of Elevated $\mathrm{CO}_{2}$ on Masson Pine Cell Wall Component Synthesis}

The plant cell wall is mainly composed of polysaccharides, which are the largest storage place for photosynthetic carbon fixation [50]. The synthesis of cell wall components is a highly complex process involving multiple enzymes and metabolic intermediates [29]. The major components of the 
cell wall, such as cellulose, hemicellulose, and pectin, require a variety of ribose compounds, most of which rely on UDP-Glc derivatization (Figure 3A) [29,51]. For the genes regulating UDP-Glc to produce hemicellulose and pectin precursor derivatives, the expression levels of GMD and RHM were higher than those of others. Due to the increased expression of $R H M$ and $G M D$ under $\mathrm{CO}_{2}$ stress, we speculate that their corresponding products (UDP-Rha and GDP-Fuc) were the main components of cell wall precursors at this stage. However, there is still no unified conclusion on its specific process of influence. Sufficient long-term research and evidence to fully and thoroughly understand the mechanism are required.

\subsection{Effects of Elevated $\mathrm{CO}_{2}$ on Masson Pine Hormones and Stomatal Regulation}

In this study, the results showed that except ZEP, the expression of each gene in the ABA synthesis pathway tended to decrease with prolonged $\mathrm{CO}_{2}$ treatment time, especially NCED. The catalysis of 9-cis-neoxanthin to Xanthoxin by NCED is a key step in the ABA metabolic pathway in plastids [52].Therefore, a decrease in the expression of NCED seriously affects the expression of other genes in the ABA metabolic pathway, which in turn affects ABA accumulation in the cell [53]. Previous studies have shown that ABA is greatly affected by BR when regulating stomatal opening and guard cell physiological states [54]. Elevated $\mathrm{CO}_{2}$ led to a sharp increase in the expression of key genes in the BR metabolic pathway, such as $C Y P$, which would inhibite ABA from binding to ABI (a kind of serine/threonine protein phosphatase), thereby weakening the effect and signal transmission of ABA [55].

For other hormones, the key genes in their synthetic pathway increased to varying degrees at the same stage. Among them, the expression of GGPS, the key gene of GA synthesis, continued to up-regulate with prolonged stress. Studies have shown that GA can divide plant hypocotyl epidermal cells, promote stomatal formation, regulate stomatal density [56], so as to maintain stomatal conductance and the transpiration rate under the condition of elevated $\mathrm{CO}_{2}$ concentration. On the other hand, according to our result, the key gene in the JA and SA synthetic pathway, including $A O C$, $L O X$ and $P A L$, remained at a high expression level with prolonged stress. It indicated that the reaction proceeded in the direction of JA and SA synthesis, which would cause stomatal closure [57-59].

In general, although previous studies have shown that ABA is the most important hormone to control stomatal switching in plants, in Masson pine under $\mathrm{CO}_{2}$ stress, the expression level of each gene in the ABA synthesis pathway was basically inhibited. However, this did not affect stomatal closure in Masson pine because the genes regulated other hormones that promote stomatal formation or induce its closure were general up-regulated in the same environment.

\section{Conclusions}

The effect of rising $\mathrm{CO}_{2}$ concentrations on plants is known, however, little research has been done on Masson pine. In this study, we tried to explore the molecular response of Masson pine under high $\mathrm{CO}_{2}$ stress. The results showed that, the genes expression would generally decrease in photosynthesis pathway (light reaction and Calvin cycle), and generally increase in other energy metabolic pathways, including TCA, EMP and PPP. At the same time, Increased $\mathrm{CO}_{2}$ concentration could also promote the gene expression in cell wall precursor synthesis pathway. In addition, $\mathrm{CO}_{2}$ stress inhibited the genes expression in the ABA synthesis pathway, but increased in other hormones synthesis pathway (including BR, GA, SA and MeJA), which might regulate stomatal density and stomatal closure. As the first report on the high-throughput sequencing of $\mathrm{CO}_{2}$ tolerant Masson pine, this study should provide novel insights into $\mathrm{CO}_{2}$ tolerance genes and be a valuable molecular basis for study in Masson pine.

Author Contributions: Conceptualization, F.W. and K.J.; software, P.Z. and J.L.; investigation, W.F., N.L. and X.S.; resources, B.Z. and N.L.; writing-original draft preparation, F.W. and X.S.; writing-review and editing, F.W. and K.J.; visualization, F.W., P.Z. and J.L.

Funding: This research was funded by the National Key R\&D Program of China (2017YFD0600304) and the Priority Academic Program Development of Jiangsu Higher Education Institutions (PAPD). 
Acknowledgments: We would like to thank Major biotechnology corporation (Shanghai, China) for assistance with sequencing services.

Conflicts of Interest: The authors declare no conflict of interest. The funders had no role in the design of the study; in the collection, analyses, or interpretation of data; in the writing of the manuscript, or in the decision to publish the results.

\section{Appendix A}

Table A1. Primers used in this study.

\begin{tabular}{|c|c|c|}
\hline Primer & & Sequence $\left(5^{\prime} \rightarrow 3^{\prime}\right)$ \\
\hline \multirow{2}{*}{ RHM } & Forward & TACGAATAGTCTCTGGCTTGTGAG \\
\hline & Reverse & TCTGGTTGTGTCCTTGACCTAATA \\
\hline \multirow{2}{*}{ CYP } & Forward & TCTATGGTGATCACTGGAGAAAGA \\
\hline & Reverse & GATGAGAGAATGGTTGAGAATGTG \\
\hline \multirow{2}{*}{ CPS } & Forward & TACTCGGTGTTATAAGTGCAGCTC \\
\hline & Reverse & CATGTAGCCCTTGACACAAAATAG \\
\hline \multirow{2}{*}{ OPR } & Forward & TACGATACGGGAACAACTACTGAA \\
\hline & Reverse & TCGAGCTCTAAAAACTGAGGAGAT \\
\hline \multirow{2}{*}{ PAL } & Forward & GAAGCCTGAGTTTACAGATCCATT \\
\hline & Reverse & CGTAAACСАСТTСААТСАСТTCАС \\
\hline \multirow{2}{*}{ CesA } & Forward & GGAAGGCTGTACTTTATCCTTCAA \\
\hline & Reverse & ATGCAAGACCAGATACAAGAGACA \\
\hline \multirow{2}{*}{ SBP } & Forward & TACCAGCCCAATAACAATAACCAC \\
\hline & Reverse & СТСТCATCCACGAAGCTAATAACC \\
\hline \multirow{2}{*}{ TPI } & Forward & СССТСТGССACTTTCTTTATGTC \\
\hline & Reverse & TCTAAGACTTCCTCACTTCTCCG \\
\hline \multirow{2}{*}{ Enolase } & Forward & AAGAGCTGCAAGGTAAAGTCTGTT \\
\hline & Reverse & TCTGATTCACCTTCAGCAGTAAAG \\
\hline \multirow{2}{*}{ qRT-PCR-RHM } & Forward & CСАCATCСТCACAGTAGAGATAGC \\
\hline & Reverse & CCGGTGATTACTACCAGAGGTAAC \\
\hline \multirow{2}{*}{ qRT-PCR-CYP } & Forward & AGGCCCTTCCTCAGAGGTTATCT \\
\hline & Reverse & CCGGAGTTGGTACTAGTCTTGGTA \\
\hline \multirow{2}{*}{ qRT-PCR-CPS } & Forward & GTCTAGAGCGGTTCACTCAGAT \\
\hline & Reverse & ССТСТСТССААСТАТСАСТGTGTC \\
\hline \multirow{2}{*}{ qRT-PCR-OPR } & Forward & GGTACCGTTCTTACTGGTTTGAGG \\
\hline & Reverse & GATCCTGTAGTTGGCTACACAGAC \\
\hline \multirow{2}{*}{ qRT-PCR-PAL } & Forward & CCCTCAGGTGGAGATTATCAG \\
\hline & Reverse & ССTCCATGTAGAGCTTTGTCTC \\
\hline \multirow{2}{*}{ qRT-PCR-CesA } & Forward & CCTGTACGGAGTAAGTTTGGTG \\
\hline & Reverse & ACCAGTGGAGGTAGATATGCTG \\
\hline \multirow{2}{*}{ qRT-PCR-SBP } & Forward & CTACAGAGATAGGAGAGGGGAAAC \\
\hline & Reverse & CTCCTGTGTATCGGAGTGTGTACT \\
\hline \multirow{2}{*}{ qRT-PCR-TPI } & Forward & ССТСССACTTCTACTAGGGTTT \\
\hline & Reverse & ACCAGCCAGGAGTAGTTAAGAGTG \\
\hline \multirow{2}{*}{ qRT-PCR-Enolase } & Forward & GGCCAGACAGATTATAGACAGC \\
\hline & Reverse & СТСТСATCTCTAGGGCCTCATA \\
\hline
\end{tabular}


Table A2. Abbreviation in this study.

\begin{tabular}{|c|c|c|c|}
\hline Abbr. & Full Name & Abbr. & Full Name \\
\hline PS & Photosystem & LEC & Light Harvesting Complex \\
\hline PC & Plastocyanin & RuBP & Ribulose-1,5-Bisphosphate \\
\hline 3-PG & 3-Phosphoglycerate & $1,3-\mathrm{DPG}$ & 1,3-Diphosphoglycerate \\
\hline PGAL & 3-Phosphoglyceraldehyde & DHAP & Dihydroxy-Acetone Phosphate \\
\hline FBP & Fructose-1,6-Diphosphate & F-6-P & Fructose-6-Phosphate \\
\hline E-4-P & Erythrose 4-Phosphate & SBP & Sedoheptulose-1,7-Diphosphate \\
\hline S-7-P & Sedoheptulose-7-Phosphate & $\mathrm{R}-5-\mathrm{P}$ & Ribose-5-Phosphate \\
\hline Ru-5-P & Ribulose-1,5-Phosphate & $\mathrm{Xu}-5-\mathrm{P}$ & Xylulose-5-Phosphate \\
\hline 6-PG & 6-Phosphogluconate & 6-PG-L & Gluconolactone-6-Phosphate \\
\hline G-6-P & Glucose-6-Phosphate & 2-PG & 2-Phosphoglycerate \\
\hline PEP & $\begin{array}{l}\text { Phosphoenolpyruvic } \\
\text { acid }\end{array}$ & $\mathrm{EP}$ & Enolpyruvic Acid \\
\hline Pyr & Pyruvic Acid & $\mathrm{AcCoA}$ & Acetyl CoA \\
\hline ICL & Isocitric Acid & KGA & $\alpha$-Ketoglutaric Acid \\
\hline SUA & Succinate Acid & H2MA & Malic Acid \\
\hline OAA & Oxaloacetic Acid & RCA & Rubisco Activase \\
\hline PGK & Phosphoglycerate Kinase & GAPD & $\begin{array}{l}\text { Glyceraldehyde-3-Phosphate } \\
\text { Dehydrogenase }\end{array}$ \\
\hline TPI & $\begin{array}{l}\text { Triose-Phosphate } \\
\text { Isomerase }\end{array}$ & TRA & Transaldolase \\
\hline FBPase & Fructose-1,6-Bisphosphatase & TKL & Transketolase \\
\hline RPI & $\begin{array}{l}\text { Ribulose Phosphate } \\
\text { Isomerase }\end{array}$ & SBPase & Sedoheptulose-1,7-Bisphosphatase \\
\hline RPK & Phosphoribulokinase & RPE & Ribulose Phosphate Epimerase \\
\hline 6-PGDH & $\begin{array}{l}\text { 6-Phosphogluconate } \\
\text { Dehydrogenase }\end{array}$ & G-6-PD & Glucose-6-Phosphate-Dehydrogenase \\
\hline G-6-Pase & Glucose-6-Phosphatase & HK & Hexokinase \\
\hline PK & Pyruvate Kinase & PGAM & Phosphoglycerate Mutase \\
\hline CS & Citrate Synthase & ICD & Isocitrate Dehydrogenase \\
\hline OGDC & $\begin{array}{l}\alpha \text {-Ketoglutarate } \\
\text { Dehydrogenase }\end{array}$ & $\mathrm{SDH}$ & Succinate Dehydrogenase \\
\hline $\mathrm{MDH}$ & Malate Dehydrogenase & $\mathrm{TP}$ & Triose Phosphate \\
\hline ADP-Glc & $\begin{array}{l}\text { Adenosine Diphosphate } \\
\text { Glucose }\end{array}$ & UDP-Glc & Uridine Diphosphate Glucose \\
\hline M-6-P & Mannose-6-Phosphate & M-1-P & Mannose-1-Phosphate \\
\hline GDP-Man & $\begin{array}{l}\text { Guanosine Diphosphate } \\
\text { Mannose }\end{array}$ & GDP-Fuc & Guanosine Diphosphate Fucose \\
\hline UDP-Rha & $\begin{array}{l}\text { Uridine Diphosphate } \\
\text { Rhamnose }\end{array}$ & UDP-Gal & Uridine Diphosphate Galacturonate \\
\hline UDP-GlcA & $\begin{array}{l}\text { Uridine Diphosphate } \\
\text { Glucuronate }\end{array}$ & UDP-Xyl & Uridine Diphosphate Xylose \\
\hline UDP-Api & $\begin{array}{l}\text { Uridine Diphosphate } \\
\text { Apiose }\end{array}$ & UDP-Arap & $\begin{array}{l}\text { Uridine Diphosphate Arabinose, } \\
\text { Pyranose form }\end{array}$ \\
\hline UDP-Araf & $\begin{array}{l}\text { Uridine Diphosphate, } \\
\text { Furanose form }\end{array}$ & FDA & Fructose-Bisphosphate Aldolase \\
\hline GPI & $\begin{array}{l}\text { Phosphoglucose } \\
\text { Isomerase }\end{array}$ & PGM & Phosphoglucomutase \\
\hline SP & Starch Phosphorylase & AGP & $\begin{array}{l}\text { Adenosine Diphosphoglucose } \\
\text { Pyrophosphorylase }\end{array}$ \\
\hline SSS & Soluble Starch Synthase & GBSS & Granule-bound Starch Synthase \\
\hline SBE & $\begin{array}{l}\text { Starch Branching } \\
\text { Enzyme }\end{array}$ & UGP & UDP-Glucose Pyrophosphorylase \\
\hline CesA & $\begin{array}{l}\text { Cellulose Synthase } \\
\text { Catalytic Subunit }\end{array}$ & Csl & Cellulose Synthase \\
\hline MPI & $\begin{array}{l}\text { Phosphomannose } \\
\text { Isomerase }\end{array}$ & PMM & Phosphomannomutase \\
\hline
\end{tabular}


Table A2. Cont.

\begin{tabular}{|c|c|c|c|}
\hline Abbr. & Full Name & Abbr. & Full Name \\
\hline MGP & $\begin{array}{l}\text { Mannose-1-Phosphate } \\
\text { Guanylyltransferase }\end{array}$ & GMD & GDP-Mannose 4,6-Dehydratase \\
\hline INV & Invertase & cwINV & Cell Wall Invertase \\
\hline SPS & $\begin{array}{l}\text { Sucrose-Phosphate } \\
\text { Synthase }\end{array}$ & SUS & Sucrose Synthase \\
\hline RHM & $\begin{array}{l}\text { Rhamnose Biosynthetic } \\
\text { Enzyme }\end{array}$ & UGE & UDP-Glucose 4-Epimerase \\
\hline UGD & UDP-Glc Dehydrogenase & UXS/AXS & UDP-Glucuronate Decarboxylases \\
\hline UAE & $\begin{array}{l}\text { UDP-Arabinose } \\
\text { 4-Epimerase }\end{array}$ & UAM & UDP-Arabinose Mutase \\
\hline $\mathrm{ABA}$ & Abscisic Acid & GA & Gibberellin \\
\hline SA & Salicylic Acid & JA & Jasmonate \\
\hline $\mathrm{BR}$ & Brassinolide & MVA & Mevalonic Acid \\
\hline IPP & $\begin{array}{l}\text { Isopentenyl } \\
\text { Pyrophosphate }\end{array}$ & $Z x$ & Zeaxanthin \\
\hline ATV & All-trans Violaxanthin & 9-cis-Nx & 9-cis-Neoxanthin \\
\hline GPP & Geranyl- Pyrophosphate & FPP & Farnesyl Pyrophosphate \\
\hline GGPP & $\begin{array}{l}\text { Geranylgeranyl } \\
\text { Pyrophosphate }\end{array}$ & CPP & Cuban Pyrophosphate \\
\hline KA & Kaurenoic Acid & Sha & Shikimic Acid \\
\hline Cha & Chorismic acid & ICA & Isochorismic Acid \\
\hline L-Aro & L-Arogenate & $\mathrm{Ca}$ & Cinnamic Acid \\
\hline $\mathrm{Ba}$ & Benzoic Acid & ALA & Linolenic Acid \\
\hline HPALA & $\begin{array}{l}\text { 13-Hydrogen Peroxide } \\
\text { Linolenic Acid }\end{array}$ & EALA & 12,13-Epoxylinolenic Acid \\
\hline OPDA & $\begin{array}{l}\text { 12-Oxophytodienoic } \\
\text { Acid }\end{array}$ & CR & Campesterol \\
\hline CHOLK & Cholesten-3-Ketone & $\mathrm{CN}$ & Campestanol \\
\hline OCN & 6-Oxocampestanol & $\mathrm{CT}$ & Cathasterone \\
\hline $6 \mathrm{DCT}$ & 6-Deoxycathasterone & $\mathrm{TE}$ & Teasterone \\
\hline 6DTE & 6-Deoxyteasterone & 3DT & 3-Dehydrocathasterone \\
\hline 6D3DT & 6-Deoxy-3-Dehydrocathasterone & TY & Typhasterol \\
\hline 6DTY & 6-Deoxytyphasterol & CS & Castasterone \\
\hline 6DCS & 6-Deoxycastasterone & OTS1 & Open Stomata 1 \\
\hline SnRK2 & $\begin{array}{l}\text { Sucrose Non-fermenting } \\
\text { 1-related Kinase }\end{array}$ & MAPK & Mitogen Activated Protein Kinase \\
\hline ZEP & Zeaxanthin Epoxidase & NCED & 9-cis-Epoxycarotenoid Dioxygenase \\
\hline SDR & $\begin{array}{c}\text { Short-chain } \\
\text { Dehydrogenase/reductase }\end{array}$ & $\mathrm{AAO}$ & ABA Aldehyde Oxidase \\
\hline ICS & Isochorismate Synthase & PAL & Phenylalanine Ammonialyase \\
\hline GGPS & Geranylgeranylpyrophosphate & CPS & Copalyl Pyrophosphate Synthase \\
\hline KS & Kaurene Synthase & $\mathrm{KO}$ & Kaurene Oxidase \\
\hline GA & Gibberellin Oxidase & LOX & Lipoxygenase \\
\hline AOS & Allene Oxide Synthase & $\mathrm{AOC}$ & Allene Oxide Cyclase \\
\hline OPR & $\begin{array}{l}\text { 12-Oxophytodienoate } \\
\text { Reductase }\end{array}$ & DWF & Trans-Cinnamate 4-Hydroxylase \\
\hline ROT & C-23 Hydroxylase & CPD & Coumarate-3-Hydroxylase \\
\hline
\end{tabular}

\section{References}

1. Liu, Y.H.; Wang, H.J.; Zhang, X.Q. The background of climate change, diplomatic and political games. In Climate Change and Forest Carbon in China; Li, T.Y., Lin, H., Eds.; China Meteorological Press: Beijing, China, 2014; pp. 9-14.

2. GCP. Carbon Budget. Available online: http://www.globalcarbonproject.org/carbonbudget (accessed on 6 July 2019). 
3. Yue, J.W. Dynamics, Potential and Mechanism of Carbon Sequestration in Major Forest Types in Gansu Province, China. Ph.D. Thesis, University of Chinese Academy of Sciences, Beijing, China, 2018.

4. Urban, O. Physiological Impacts of Elevated $\mathrm{CO}_{2}$ Concentration Ranging from Molecular to Whole Plant Responses. Photosynthetica 2003, 41, 9-20. [CrossRef]

5. Chen, G.Y.; Yong, Z.H. Photosynthetic Acclimation in Rice Leaves to Free-air $\mathrm{CO}_{2}$ Enrichment Related to Both Ribulose-1,5-bisphosphate Carboxylation Limitation and Ribulose-1,5-bisphosphate Regeneration Limitation. Plant Cell Physiol. 2005, 46, 1036-1045. [CrossRef] [PubMed]

6. Ainsworth, E.A.; Rogers, A. The response of photosynthesis and stomatal conductance to rising $\left[\mathrm{CO}_{2}\right]$ : Mechanisms and environmental interactions. Plant Cell Environ. 2007, 30, 258-270. [CrossRef] [PubMed]

7. Ashraf, M.; Akram, N.A.; Arteca, R.N. The Physiological, Biochemical and Molecular Roles of Brassinosteroids and Salicylic Acid in Plant Processes and Salt Tolerance. Crit. Rev. Plant Sci. 2010, 29, 162-190. [CrossRef]

8. Pan, C.Z.; Zhang, H.; Ma, Q.M.; Fan, F.J. Role of ethylene biosynthesis and signaling in elevated $\mathrm{CO}_{2}$-induced heat stress response in tomato. Planta 2019, 250, 563-572. [CrossRef] [PubMed]

9. Romero, I.; Alegria, C.E.; Pradena, A.G. WRKY transcription factors in the response of table grapes (cv. Autumn Royal) to high CO2 levels and low temperature. Postharvest Biol. Technol. 2018, 150, 42-51.

10. Zou, X.L.; Shen, Q.J.X.; Neuman, D. An ABA inducible WRKY gene integrates responses of creosote bush (Larrea tridentata) to elevated $\mathrm{CO}_{2}$ and abiotic stresses. Plant Sci. 2007, 172, 997-1004. [CrossRef]

11. Ni, Z.X.; Ye, Y.J.; Bai, T.D.; Xu, M.; Xu, L.A. Complete Chloroplast Genome of Pinus massoniana (Pinaceae): Gene Rearrangements, Loss of ndh Genes, and Short Inverted Repeats Contraction, Expansion. Molecules 2017, 22, 1528. [CrossRef]

12. Guo, Y. Changes in Total Stand Biomass of Pinus Massoniana Forests and Its Response to Age Class Structure in Hunan Province, China. Master's, Thesis, Central South University of Forestry and Technology, Hunan, China, 2015.

13. Justine, M.F.; Yang, W.Q.; Wu, F.Z.; Khan, M.N. Dynamics of biomass and carbon sequestration across a chronosequence of Masson pine plantations. J. Geophys. Res. Biogeosci. 2017, 122, 578-591. [CrossRef]

14. Elias, M.; Potvin, C. Assessing inter-and intra-specific variation in trunk carbon concentration for 32 neotropical tree species. Can. J. For. Res. 2003, 33, 1039-1045. [CrossRef]

15. Banerjee, S.; Siemianowski, O.; Liu, M.L.; Lind, K.R. Stress response to $\mathrm{CO}_{2}$ deprivation by Arabidopsis thaliana in plant cultures. PLoS ONE 2019, 14, e0212462. [CrossRef] [PubMed]

16. Kumar, A.; Castellano, I.; Patti, F.P. Molecular response of Sargassum vulgare to acidification at volcanic $\mathrm{CO}_{2}$ vents: Insights from de novo transcriptomic analysis. Mol. Ecol. 2017, 26, 2276-2290. [CrossRef] [PubMed]

17. DeSouza, A.P.; Cocuron, J.C.; Garcia, A.C.; Alonso, A.P.; Buckeridge, M.S. Changes in Whole-Plant Metabolism during the Grain-Filling Stage in Sorghum Grown under Elevated $\mathrm{CO}_{2}$ and Drought. Plant Physiol. 2015, 169, 1755-1765. [CrossRef] [PubMed]

18. Martin, M. Cutadapt removes adapter sequences from high-throughput sequencing reads. EMBnet J. 2011, 17, 10-12. [CrossRef]

19. Haas, B.J.; Papanicolaou, A.; Yassour, M.; Grabherr, M.; Blood, P.D.; Bowden, J.; Couger, M.B.; Eccles, D.; Li, B.; Lieber, M.; et al. De novo transcript sequence reconstruction from RNA-seq using the Trinity platform for reference generation and analysis. Nat. Protoc. 2013, 8, 1494-1512. [CrossRef] [PubMed]

20. Smith-Unna, R.; Boursnell, C.; Patro, R.; Hibberd, J.M.; Kelly, S. TransRate: Reference-free quality assessment of de novo transcriptome assemblies. Genome Res. 2016, 26, 1134-1144. [CrossRef] [PubMed]

21. Simão, F.A.; Waterhouse, R.M.; Ioannidis, P. BUSCO: Assessing genome assembly and annotation completeness with single-copy orthologs. Bioinformatics 2015, 31, 3210-3212. [CrossRef]

22. Li, B.; Dewey, C.N. RSEM: Accurate transcript quantification from RNA-Seq data with or without a reference genome. BMC Bioinform. 2011, 12, 323. [CrossRef]

23. Wang, L.K.; Feng, Z.X.; Wang, X.; Wang, X.W.; Zhang, X.G. DEGseq: An R package for identifying differentially expressed genes from RNA-seq data. Bioinformatics 2010, 26, 136-138. [CrossRef]

24. Anders, S.; Huber, W. Differential expression analysis for sequence count data. Genome Biol. 2010, 11, R106. [CrossRef]

25. Zhu, P.; Ma, Y.; Zhu, L.; Chen, Y.; Li, R.; Ji, K. Selection of Suitable Reference Genes in Pinus massoniana Lamb. Under Different Abiotic Stresses for qPCR Normalization. Forests 2019, 10, 632. [CrossRef] 
26. Fan, F.H.; Wang, Q.H.; Wen, X.P.; Ding, G.J. Transcriptome-wide identification and expression profiling of Pinus massoniana MYB transcription factors responding to phosphorus deficiency. J. For. Res. 2019, 20. [CrossRef]

27. Du, M.F.; Ding, G.J.; Cai, Q. The Transcriptomic Responses of Pinus massoniana to Drought Stress. Forests 2018, 9, 326. [CrossRef]

28. Sarka, E.; Dvoracek, V. Biosynthesis of waxy starch-a review. Plant Soil Environ. 2017, 63, 335-341.

29. Verbancic, J.; Lunn, J.E.; Stitt, M.; Persson, S. Carbon Supply and the Regulation of Cell Wall Synthesis. Mol. Plant 2018, 11, 75-94. [CrossRef]

30. Bashar, K.K.; Tareq, M.Z.; Amin, M.R.; Honi, U. Phytohormone-Mediated Stomatal Response, Escape and Quiescence Strategies in Plants under Flooding Stress. Agronomy 2019, 9, 43. [CrossRef]

31. Huang, H.; Liu, B.; Liu, L.Y.; Song, S.S. Jasmonate action in plant growth and development. J. Exp. Bot. 2017, 68, 1349-1359. [CrossRef]

32. Ha, Y.M.; Shang, Y.; Yang, D.; Nam, K.H. Brassinosteroid reduces ABA accumulation leading to the inhibition of ABA-induced stomatal closure. Biochem. Biophys. Res. Commun. 2018, 504, 143-148. [CrossRef]

33. Miura, K.; Tada, Y. Regulation of water, salinity, and cold stress responses by salicylic acid. Front. Plant Sci. 2014, 5, 4. [CrossRef]

34. Hernandez-Ruiz, J.; Arnao, M.B. Relationship of Melatonin and Salicylic Acid in Biotic/Abiotic Plant Stress Responses. Agronomy 2018, 8, 33. [CrossRef]

35. Zhao, B.L.; Li, J. Regulation of Brassinosteroid Biosynthesis and Inactivation. J. Integra. Plant Biol. 2012, 54, 746-759. [CrossRef] [PubMed]

36. Xie, H.; Fan, G.Z.; Jin, Y.H.; Dong, L.; Deng, F.H. Progress of Research on Photosynthetic Acclimation of Plant to Elevated Atmospheric $\mathrm{CO}_{2}$. Rev. China Agric. Sci. Technol. 2006, 8, 29-34.

37. Drake, B.G.; Gonzalez-Meler, M.A.; Long, S.P. More Efficient Plants: A Consequence of Rising Atmospheric $\mathrm{CO}_{2}$. Ann. Rev. Plant Biol. 1997, 48, 609-639. [CrossRef] [PubMed]

38. Sreeharsha, R.V.; Mudalkar, S.; Sengupta, D.; Unnikrishnan, D.K.; Reddy, A.R. Mitigation of drought-induced oxidative damage by enhanced carbon assimilation and an efficient antioxidative metabolism under high $\mathrm{CO}_{2}$ environment in pigeonpea (Cajanus cajan L.). Photosynth. Res. 2019, 139, 425-439. [CrossRef] [PubMed]

39. $\mathrm{Xu}, \mathrm{M}$.Y. Effect of Elevated $\mathrm{CO}_{2}$ on Photosynthetic Characteristics and Molecular Mechanism in Deyeuxia Angustifolia. Ph.D. Thesis, Northeast Agricultural University, Harbin, China, 2015.

40. Xu, S.; Chen, W.; He, X.Y.; Huang, Y.Q.; Gao, J.Y.; Zhao, Y.; Li, B. Research advance in effect of elevated $\mathrm{CO}_{2}$ on eco-physiology of trees. Acta Ecol. Sin. 2015, 35, 2452-2460.

41. Turnbull, M.H.; Tissue, D.T.; Griffin, K.L.; Rogers, G.N.D.; Whitehead, D. Photosynthetic acclimation to long-term exposure to elevated $\mathrm{CO}_{2}$ concentration in Pinus radiata D. Don is related to age of needles. Plant Cell Environ. 1998, 21, 1019-1028. [CrossRef]

42. Fukayama, H.; Sugino, M.; Fukuda, T. Gene expression profiling of rice grown in free air $\mathrm{CO}_{2}$ enrichment (FACE) and elevated soil temperature. Field Crops Res. 2011, 121, 195-199. [CrossRef]

43. Sicher, R. Combined effects of $\mathrm{CO}_{2}$ enrichment and elevated growth temperatures on metabolites in soybean leaflets: Evidence for dynamic changes of TCA cycle intermediates. Planta 2013, 238, 369-380. [CrossRef]

44. Liu, L.X.; Shen, F.F.; Lu, H.C.; Han, O.D.; Liu, Y.G. Research Advance on Sucrose Phosphate Synthase in Sucrose Metabolism. Mol. Plant Breed. 2005, 3, 275-281.

45. Van Le, Q.U.Y.; Samson, G.U.Y.; Desjardins, Y. Opposite effects of exogenous sucrose on growth, photosynthesis and carbon metabolism of in vitro plantlets of tomato (L. Esculentum Mill.) grown under two levels of irradiances and $\mathrm{CO}_{2}$ concentration. J. Plant Physiol. 2001, 158, 599-605. [CrossRef]

46. Qian, W.; Yue, C.; Wang, Y.; Cao, H.; Li, N.; Wang, L.; Hao, X.; Wang, X.; Xiao, B.; Yang, Y. Identification of the invertase gene family (INVs) in tea plant and their expression analysis under abiotic stress. Plant Cell Rep. 2016, 35, 2269-2283. [CrossRef] [PubMed]

47. Yue, C.; Cao, H.L.; Wang, L.; Zhou, Y.H.; Huang, Y.T.; Hao, X.Y.; Wang, Y.C.; Wang, B.; Yang, Y.J.; Wang, X.C. Effects of cold acclimation on sugar metabolism and sugar-related gene expression in tea plant during the winter season. Plant Mol. Biol. 2015, 88, 591-608. [CrossRef] [PubMed]

48. Tetlow, I.J. Understanding storage starch biosynthesis in plants: A means to quality improvement. Can. J. Bot. 2006, 84, 1167-1185. [CrossRef] 
49. Cui, H. Effects of $\mathrm{CO}_{2}$ Concentration and Nitrogen Application on Grain Yield, Quality Formation and Their Physiology Mechanism in Winter Wheat. Master's Thesis, Nanjing Agricultural University, Nanjing, China, 2011.

50. Anderson, C.T.; Wallace, I.S. Illuminating the wall: Using click chemistry to image pectins in Arabidopsis cell walls. Plant Signal. Behav. 2012, 7, 661-663. [CrossRef] [PubMed]

51. Diez, M.D.A.; Peiru, S.; Demonte, A.M.; Gramajo, H.; Iglesias, A.A. Characterization of Recombinant UDP-and ADP-Glucose Pyrophosphorylases and Glycogen Synthase to Elucidate Glucose-1-Phosphate Partitioning into Oligo- and Polysaccharides in Streptomyces coelicolor. J. Bacteriol. 2012, 194, 1485-1493. [CrossRef] [PubMed]

52. Hwang, S.G.; Chen, H.C.; Huang, W.Y.; Chu, Y.C.; Shii, C.T.; Cheng, W.H. Ectopic expression of rice OsNCED3 in Arabidopsis increases ABA level and alters leaf morphology. Plant Sci. 2010, 178, 12-22. [CrossRef]

53. De Souza, A.M.S.; Batista, V.G.L.; Pinheiro, M.P.N.; Suassuna, J.F.; de Lima, L.M.; Fernandes, P.D. Expression of NCED gene in colored cotton genotypes subjected to water stress. Rev. Bras. Eng. Agric. Ambient. 2016, 20, 692-696. [CrossRef]

54. Haubrick, L.L.; Torsethaugen, G.; Assmann, S.M. Effect of brassinolide, alone and in concert with abscisic acid, on control of stomatal aperture and potassium currents of Vicia faba guard cell protoplasts. Physiol. Plant. 2006, 128, 134-143. [CrossRef]

55. Hu, Y.R.; Yu, D.Q. BRASSINOSTEROID INSENSITIVE2 Interacts with ABSCISIC ACID INSENSITIVE5 to Mediate the Antagonism of Brassinosteroids to Abscisic Acid during Seed Germination in Arabidopsis. Plant Cell 2014, 26, 4394-4408. [CrossRef]

56. Barton, C.V.M.; Duursma, R.A.; Medlyn, B.E.; Ellsworth, D.S. Effects of elevated atmospheric $\left[\mathrm{CO}_{2}\right]$ on instantaneous transpiration efficiency at leaf and canopy scales in Eucalyptus saligna. Glob. Chang. Biol. 2012, 18, 585-595. [CrossRef]

57. Gao, C.J.; Xia, X.J.; Shi, K.; Zhou, Y.H.; Yu, J.Q. Response of Stomata to Global Climate Changes and the Underlying Regulation Mechanism of Stress Responses. Plant Physiol. J. 2012, 48, 19-28.

58. Islam, M.M.; Munemasa, S.; Hossain, M.A.; Nakamura, Y.; Mori, I.C.; Murata, Y. Roles of AtTPC1, Vacuolar Two Pore Channel 1, in Arabidopsis Stomatal Closure. Plant Cell Physiol. 2010, 51, 302-311. [CrossRef] [PubMed]

59. Wang, L.J.; Fan, L.; Loescher, W.; Duan, W.; Liu, G.J. Salicylic acid alleviates decreases in photosynthesis under heat stress and accelerates recovery in grapevine leaves. BMC Plant Biol. 2010, 10, 34. [CrossRef] [PubMed] 